\title{
Clinical findings among hard metal workers
}

\author{
Alf Fischbein, Jiin-Chyuan J Luo, Stephen J Solomon, Stephen Horowitz, Wajdy Hailoo, \\ Albert Miller
}

\begin{abstract}
In 1940, the first report appeared describing a pulmonary disorder associated with occupational exposures in the cemented tungsten carbide industry. The disease, known as "hard metal disease," has subsequently been characterised in detail and comprises a wide range of clinical signs and symptoms. In this report, clinical findings in a group of 41 hard metal workers employed until recently are described. A high prevalence of respiratory symptoms was found. Thirteen workers $(31 \%)$ had abnormal chest radiographs indicative of interstitial lung disease. Fifty per cent of these had been employed in hard metal manufacturing for less than 10 years. Abnormalities of pulmonary function were also frequent and included a restrictive pattern of impairment and decrease in diffusing capacity (27\%). Associations were found between diffusing capacity, chest radiographic abnormalities and right ventricular ejection fraction at exercise indicating cardiopulmonary effects. The findings show the continuous need to control excessive occupational exposures to prevent hard metal disease, the history of which now enters its sixth decade.
\end{abstract}

During the first decades of this century, a metallurgical process was developed for the production of hard metals. These are typically alloys of tungsten carbide, titanium carbide, and cobalt. Occasionally,

Division of Environmental and Occupational Medicine, Mount Sinai School of Medicine of the City University of New York, New York 10029, USA A Fischbein, J-C J Luo, W Hailoo

Department of Biomathematical Sciences, Mount Sinai Medical Center, New York, New York 10029

S J Solomon

Department of Cardiology, Beth Israel Medical Center, New York, New York 10003

$S$ Horowitz

Pulmonary Division, Department of Medicine, Mount Sinai Medical Center, New York New York 10029

A Miller small amounts of other metals such as vanadium, tantalum, niobium, nickel, and chromium are incorporated into the hard metal. ${ }^{1}$ Cobalt serves as a binder (cement) in such alloys, and the manufacturing of such products is widely known as the cemented tungsten carbide industry. The manufacture is based on a metallurgical process that involves mixing metal ingredients and binders in powder form. Hard metal alloys are formed under high pressure, heated in furnaces, and shaped into the final products. These are typically cutting or drilling tools. The products undergo precision grinding and honing for final shaping. The hard metal product is very resistant and has a hardness similar to that of diamond. ${ }^{2}$

The main occupational respiratory hazard associated with employment in this industry results from the effects of excessive inhalation of airborne dusts and aerosols containing cobalt. A multifactorial origin of the pulmonary abnormalities associated with such exposures has recently been suggested. ${ }^{3}$ Although potential exists for exposure to various compounds in the course of the manufacturing processes, it is generally thought that the principal diseases associated with exposures in this industry are consequences of the toxic effects of cobalt. ${ }^{4-6}$ Acute, subacute, and chronic pulmonary effects attributed to cobalt include asthma, fibrosing alveolitis, and interstitial pulmonary fibrosis. The last clinicopathological entity, often used synonymously with fibrosing alveolitis, is known as "hard metal disease." Histopathological hallmarks of this disease are giant cell interstitial pneumonia and the presence of multinucleated giant cells. ${ }^{78}$ These cells can also be detected in bronchoalveolar lavage fluid. ${ }^{9}$ Cardiomyopathy associated with cobalt is a rare clinical occurrence in industrial settings..$^{10} \mathrm{It}$ is a well known disease of the past, however, associated with the ingestion of beer containing high concentrations of cobalt, which resulted in epidemic outbreaks of cardiomyopathy. ${ }^{11}$ Allergic dermatitis can also be a practical occupational health problem of significant magnitude in the hard metal industry. ${ }^{12}$

In this paper, we report findings from an investigation of a group of workers engaged in manufacturing and processing of hard metal tools. The study developed as a result of our awareness of two patients from the study population who had developed hard 
metal disease, ${ }^{13}$ and whose condition served as a health sentinel event.

\section{Materials and methods}

The study population consisted of 41 workers (27 men and 14 women). They were examined between 1982 and 1985 . Fifteen of the male workers had been employed in one particular plant in which mixing and forming of the metal powder also took place as well as grinding of hard metal tools. Twenty six workers had been employed in a plant in which only grinding was performed. All 41 workers were volunteers, and were examined because of their concern over adverse health effects that may have been related to their work environment. Their most recent employment in hard metal processing was in 1982 and none were working in this industry at the time of the examination.

Each person was interviewed about lifetime occupational experience. Information was obtained about job category while employed in hard metal manufacturing. The main job categories recorded included grinding, mixing of powders, sandblasting of hard metal objects, shipping, janitors' duties, and combinations of jobs. Total duration of employment with hard metals and the number of years that had elapsed between the start of employment and the date of the examination were recorded.

In reviewing symptoms, special emphasis was given to respiratory symptoms such as persistent cough, sputum production, dyspnoea, and history of wheezing and chest pain. An attempt was made to distinguish between "past" symptoms, defined as those being present two years before the examination and "current" symptoms-namely those either of more recent origin or those present at the time of the examination.

Review of medical history and non-respiratory symptoms was also performed. Each subject underwent a comprehensive physical examination with special emphasis on examination of the cardiopulmonary system.

Full size $14^{\prime \prime} \times 17^{\prime \prime}$ standard chest radiographs were taken and interpreted according to the International Labour Office international classification of radiographs of pneumoconioses, $1980 .^{14}$ This is a classification by which radiological changes consistent with pneumoconiosis can be assessed and reported in a standardised manner. Small opacities are characterised as rounded or irregular and the profusion is described and quantified as a 12 point numerical scale ranging from $0 /-$ to $3 /+$. Chest $x$ ray films with a reading of $1 / 0$ or higher were classified as abnormal.

Pulmonary function tests consisted of spirometry with maximum expiratory flow volume curves (MEFC) and single breath diffusing capacity $\left(D_{L} C O\right)$. Spirometry adhered to the American Thoracic Society recommendations ${ }^{15}$ and was per- formed using a rolling seal spirometer. Subjects were upright and wore a nose clip. The $\mathrm{D}_{\mathrm{L}} \mathrm{CO}$ values were means of two results that agreed within $10 \%$. Normal values for spirometry were those of Morris $e t a l^{16}$ as modified in $1980 .{ }^{17}$ For $D_{L} C O$, normal values were those of Miller et al ${ }^{18}$ using a similar demand valve system. The normal values for $\mathrm{D}_{\mathrm{L}} \mathrm{CO}$ are smoking specific-that is, considering differences between non-smokers, ex-smokers, and current smokers.

Thirty of the 41 workers also underwent detailed cardiological examination that included gated blood pool imaging, at rest and with graded supine bicycle exercise, for the assessment of left and right ventricular function. The principal results of this examination have been reported elsewhere. ${ }^{19}$ Additional findings on the association between right ventricular function and pulmonary function are presented here.

All the data obtained were encoded and entered into the computer system of the City University of New York. The data were analysed with the assistance of the Statistical Analysis System (SAS) software package. Student's $t$ test and one way analysis of variance models (ANOVA) were performed to compare mean values of pulmonary function tests and ventricular ejection fraction for classification categories based on smoking histories, chest $x$ ray findings, duration of employment, and latency (duration since first employment). Chi square statistics were calculated to test the significance of differences in prevalence of respiratory symptoms among smoking categories. Fisher's exact 2 tail test was also used to test the significance of differences in prevalence of respiratory symptoms stratified by chest $x$ ray film abnormalities. Pearson correlation coefficients were computed to explore associations. Stepwise multiple regression models were also performed to identify the best combination of variables, such as chest $x$ ray film abnormalities, smoking state, dyspnoea, and latency that predicted pulmonary function values and ventricular ejection fraction. Logistic regression analyses gave the magnitude and significance of the effect of latency on the presence of radiological abnormalities after controlling for smoking state and other covariates.

\section{Results}

Thirty five workers (86\%) listed grinding as their primary job category. Four male workers had either performed sandblasting, grinding, and mixing, or worked in other capacities not directly related to the production process. Among the women, one had worked in the shipping department while another listed sandblasting and work in the shipping department as primary job categories.

The mean age of the examined group was 42.7 (SD 9.3) years. Table 1 shows the age distribution. 
Table 1 Age distribution of 41 hard metal workers

\begin{tabular}{lc}
\hline Age $(y)$ & No of workers $(\%)$ \\
\hline$<40$ & $13(31 \cdot 7)$ \\
$40-49$ & $20(48 \cdot 8)$ \\
$50-59$ & $5(12 \cdot 2)$ \\
$\geqslant 60$ & $3(7 \cdot 3)$ \\
Total & $41(100 \cdot 0)$ \\
\hline
\end{tabular}

Most workers $(33(80 \cdot 5 \%))$ were younger than 50 . Twenty workers (48.8\%) were between 40 and 49 . The mean duration of employment for the examined workers was 10.5 (SD 5.3) years. Table 2 shows the distribution of duration of employment. Twenty workers $(48.8 \%)$ had a duration of employment of 10 years or longer and only seven workers $(17 \cdot 1 \%)$ had been employed for five years or less. The mean duration since first employment in the trade was 14.8 (SD $5 \cdot 2$ years; range five to 23 years).

With regard to smoking histories, $19(46.3 \%)$ were current smokers. Fourteen (34.2\%) were ex-smokers, 13 of whom had discontinued cigarette smoking within two years of the examination. Eight (19.5\%) had never smoked cigarettes regularly.

\section{RESPIRATORY SYMPTOMS}

There was a high prevalence of respiratory symptoms in the study group. Table 3 summarises the frequencies of respiratory symptoms reported at the examination. It is of interest to note that 34 subjects $(82.9 \%)$ reported dyspnoea on exertion. Twenty three workers $(56 \cdot 1 \%)$ gave a history of cough, 17 of whom $(41.5 \%)$ gave a history of sputum production in association with the cough. Seventeen workers $(41.5 \%)$ also reported wheezing as a significant symptom. None had ever experienced haemoptysis. A history of multiple respiratory symptoms was common. Thirty one workers $(75 \cdot 6 \%)$ reported two symptoms and $15(36.6 \%)$ gave a history of four respiratory symptoms.

We also attempted to explore the prevalence of respiratory symptoms experienced by the workers in the past - that is, two years before the examination. This was of interest, as none of the workers were employed in the cemented tungsten carbide industry at the time of the examination. Table 4 shows the prevalence of such symptoms. It can be seen that the prevalences of "past" and "current" symptoms were

Table 2 Duration of employment of 41 hard metal workers

\begin{tabular}{ll}
\hline Years & No of workers $(\%)$ \\
\hline$<5$ & $7(17 \cdot 1)$ \\
$5-9$ & $14(34 \cdot 1)$ \\
$10-15$ & $10(24 \cdot 4)$ \\
$\geqslant 15$ & $10(24 \cdot 4)$ \\
Total & $41(100 \cdot 0)$ \\
\hline
\end{tabular}

Table 3 Prevalence of respiratory symptoms reported

\begin{tabular}{ll}
\hline Symptom & No of workers (\%) \\
\hline Cough & $23(56 \cdot 1)$ \\
Dyspnoea & $34(82 \cdot 9)$ \\
Sputum & $17(41 \cdot 5)$ \\
Wheezing & $17(41 \cdot 5)$ \\
Chest pain & $13(31 \cdot 7)$ \\
\hline
\end{tabular}

similar except for a significant $(1 \cdot 4$-fold $)$ increase over time in the reporting of dyspnoea as a current symptom.

Respiratory symptoms were also analysed with regard to smoking state. Of the 34 workers with a history of dyspnoea on exertion, $18(52.9 \%)$ were smokers whereas $16(47 \cdot 1 \%)$ belonged to the nonsmoking categories ( 10 were ex-smokers and six had never smoked cigarettes). The difference was not statistically significant $\left(\chi^{2}=3.53, \mathrm{p}=0.19\right)$. The symptoms of cough and phlegm production occurred with equal frequencies among workers of the three smoking categories: five $(62.5 \%)$ of the eight nonsmokers presented with persistent cough and four of them $(50 \cdot 0 \%)$ had a productive cough.

\section{RADIOLOGICAL FINDINGS}

Abnormal chest radiographs interpreted according to the ILO classification were found in 13 workers $(31 \cdot 7 \%)$. Five were graded $1 / 0$, seven as $1 / 1$ and one was graded $1 / 2$ for reticulonodular opacities. No differences were found between those with and without abnormal chest radiographs with respect to age, duration of employment, or duration from onset of first employment. For example, the mean duration of employment for those with normal chest radiographs was $10 \cdot 2$ (SD $4 \cdot 7)$ years as compared to a mean of 11.0 (SD 6.6) years for the workers with abnormal films ( $t=0.42 ; p=0.68)$. In fact, six $(46 \cdot 1 \%)$ of the workers with abnormal chest radiographs had been employed for less than 10 years in the industry.

When the radiographic abnormalities were analysed in relation to smoking category by $t$ test, the eight non-smokers had a borderline significantly higher degree of $x$ ray film abnormalities (profusion score according to the ILO classification) than the 33 current smokers and ex-smokers $(t=1 \cdot 78$; $p=0.083$ )

Respiratory symptoms were reported with equal

Table 4 Prevalence of past respiratory symptoms of 41 hard metal workers

\begin{tabular}{ll}
\hline Symptom & No of workers $(\%)$ \\
\hline Cough & $21(51 \cdot 2)$ \\
Dyspnoea & $24(58 \cdot 5)$ \\
Sputum & $13(31 \cdot 7)$ \\
Wheezing & $15(36 \cdot 6)$ \\
Chest pain & $9(21 \cdot 9)$ \\
\hline
\end{tabular}


Table 5 Comparing means (SD) values of pulmonary function tests and right ventricular ejection fraction (RVEF) with regard to smoking categories, latency periods $(<10 y, \geq 10 y)$, and chest $x$ ray film findings (normal, abnormal)

\begin{tabular}{|c|c|c|c|c|c|c|c|}
\hline \multirow[b]{2}{*}{ Parameter } & \multicolumn{3}{|l|}{ Smoking state } & \multicolumn{2}{|l|}{ Latency } & \multicolumn{2}{|c|}{ Chest $x$ ray film } \\
\hline & Non-smoker & Ex-smoker & Current smoker & $<10 y$ & $\geq 10 y$ & Normal & Abnormal \\
\hline $\begin{array}{l}\text { FVC } \\
\text { FEV }_{1} \\
\text { FEV }_{1} / \text { FVC } \\
\text { FEF }_{25-75} \\
\text { DLCO } \\
\text { MET } \\
\text { MVV } \\
\text { RVEF-R } \\
\text { RVEF-E } \\
\text { RVEF change }\end{array}$ & $\begin{array}{c}85.1(11.3) \\
92.5(14.3) \\
107.8(10.4) \\
94.4(31.0) \\
84.8(16.0) \\
0.62(0.28) \\
188 \cdot 1(210.8) \\
39.7(6.0) \\
46.0(5.6) \\
6.3(5.0)\end{array}$ & $\begin{array}{c}90.5(15.7) \\
95 \cdot 1(20.3) \\
104.4(13.1) \\
89.3(30.9) \\
85.6(11.4) \\
0.77(0.50) \\
111.4(25.1) \\
41.1(5 \cdot 4) \\
50.1(6.0) \\
9.0(2.0)\end{array}$ & $\begin{array}{c}86 \cdot 5(15 \cdot 1) \\
89 \cdot 2(18 \cdot 7) \\
101.6(11 \cdot 3) \\
78.9(30 \cdot 1) \\
82.0(21 \cdot 2) \\
0.76(0 \cdot 36) \\
99 \cdot 2(31 \cdot 3)^{\star} \\
40.9(4 \cdot 9) \\
49.9(8 \cdot 2) \\
9.1(7 \cdot 7)\end{array}$ & $\begin{array}{c}105.4(17.5) \\
113.0(17.5) \\
106.7(9 \cdot 1) \\
109.9(29.9) \\
84.0(17 \cdot 9) \\
0.58(0.13) \\
121.0(44.5) \\
39 \cdot 3(4 \cdot 2) \\
52.7(8 \cdot 0) \\
13.4(5 \cdot 7)\end{array}$ & $\begin{array}{c}83.9(10.8) \ddagger \\
87.5(14.9) \ddagger \\
103.2(12.5) \\
80.4(28.5) \dagger \\
83.7(17 \cdot 2) \\
0.77(0.42) \\
120.6(106 \cdot 1) \\
41 \cdot 1(5 \cdot 3) \\
48 \cdot 1(6.8) \\
7.0(5 \cdot 5)\end{array}$ & $\begin{array}{c}89.7(13.3) \\
93.0(18.4) \\
102 \cdot 1(12 \cdot 1) \\
84.2(30.8) \\
88.9(16.0) \\
0.76(0.42) \\
105 \cdot 0(28 \cdot 4) \\
41.6(4.7) \\
51.7(6.9) \\
10.2(6.0)\end{array}$ & $\begin{array}{c}83 \cdot 2(16.3) \\
89.3(18.5) \\
107.4(10.4) \\
88 \cdot 2(30 \cdot 8) \\
72 \cdot 8(14.3)^{\star \star \star} \\
0.68(0.35) \\
154.5(168 \cdot 3) \\
39 \cdot 2(5 \cdot 6) \\
44.8(5.5)^{\star \star \star} \\
5.6(5.3)^{\star \star}\end{array}$ \\
\hline
\end{tabular}

${ }^{\star} p<0.05$ comparing current smokers with non-smokers.

tp $<0.05$ comparing latency ( $\geq 10$ years) with ( $<10$ years).

$\ddagger \mathrm{p}<0.001$ comparing latency ( $\geq 10$ years) with ( $<10$ years).

$\star \star p<0.05$ comparing abnormal chest $x$ ray film with normal chest $x$ ray film.

$\star \star \star p<0.01$ comparing abnormal chest $x$ ray film with normal chest $x$ ray film.

frequency among those with normal and abnormal chest radiographs. For example, of the 13 workers who had abnormal chest radiographs, $11(84 \cdot 5 \%)$ reported dyspnoea on exertion, and $23(82 \cdot 1 \%)$ of the 28 workers with normal chest $x$ ray films had these symptoms (Fisher's 2 tailed exact test, $\mathrm{p}=1 \cdot 00$ ). Among the 17 workers with a history of wheezing, four $(23.5 \%)$ had abnormal chest radiographs.

\section{PULMONARY FUNCTION TESTS}

Eighteen workers $(43.9 \%)$ had completely normal pulmonary function test results, and $10(24.4 \%)$ showed at least one pattern of impairment, either an obstructive or restrictive defect. Thirteen workers $(31.4 \%)$ had combinations of abnormalities in their pulmonary function.

Of the 13 subjects with abnormal FVC, eight $(61.5 \%)$ were current smokers, three $(33.1 \%)$ were ex-smokers, and two $(15.4 \%)$ had no history of cigarette smoking. With regard to abnormalities in $\mathrm{FEV}_{1} / \mathrm{FVC}$, all six abnormalities found occurred in either current smokers or ex-smokers. Among the 11 subjects with abnormal $\mathrm{D}_{\mathrm{L}} \mathrm{CO}$, six $(54 \cdot 6 \%)$ were current smokers, three $(27 \cdot 3 \%)$ were ex-smokers, and two $(18 \cdot 2 \%)$ had no history of cigarette smoking. Thus the abnormalities in FVC and $\mathrm{D}_{\mathrm{L}} \mathrm{CO}$ did not show statistically significant differences between the various smoking categories.

Small airways dysfunction (abnormal $\mathrm{FEF}_{25-75}$, or mean expiratory time, or both), was found in nine workers $(21.9 \%)$ six of whom were smokers.

Significantly lower mean values of FVC \% predicted, $\mathrm{FEV}_{1} \%$ predicted, $\mathrm{FEF}_{25-75} \%$ predicted, and longer MET were found for those workers for whom 10 years or more had elapsed since first employment in the trade as compared with the workers who had been first employed within the 10 year period preceding the examination (table 5). With regard to the association between duration of employment and pulmonary function tests, 10 years or longer employment history was associated with significantly lower mean values of $\mathrm{FEV}_{1} \%$ predicted $(\mathrm{t}=2 \cdot 12$; $\mathrm{p}=0.042), \quad \mathrm{FEF}_{25-75} \% \quad$ predicted $\quad(\mathrm{t}=2.46 ;$ $\mathrm{p}=0.018)$, and longer MET $(\mathrm{t}=1.79 ; \mathrm{p}=0.008)$.

Significant negative correlation was noted between radiographic abnormalities (as ILO profusion score or as categorical variable) and diffusing capacity $(\mathrm{r}=-0.43, \mathrm{p}=0.005$ and $\mathrm{r}=-0.44, \mathrm{p}=0.004)$.

Table 6 Regression coefficients (B) between the independent variables-smoking state, latency, chest $x$ ray film abnormalities, dyspnoea, and the dependent variables-predicted \% of pulmonary function test

\begin{tabular}{|c|c|c|c|c|c|c|c|c|c|c|c|c|c|c|}
\hline \multirow[b]{2}{*}{ Category } & \multicolumn{2}{|l|}{$F V C$} & \multicolumn{2}{|l|}{$F E V_{1}$} & \multicolumn{2}{|c|}{$F E V, / F V C$} & \multicolumn{2}{|l|}{$F E V_{25-75}$} & \multicolumn{2}{|l|}{$D L C O$} & \multicolumn{2}{|l|}{$M E T$} & \multicolumn{2}{|l|}{$\underline{M V V}$} \\
\hline & $\begin{array}{l}\text { Initial } \\
\text { model }\end{array}$ & $\begin{array}{l}\text { Best } \\
\text { model }\end{array}$ & $\begin{array}{l}\text { Initial } \\
\text { model }\end{array}$ & $\begin{array}{l}\text { Best } \\
\text { model }\end{array}$ & $\begin{array}{l}\text { Initial } \\
\text { model }\end{array}$ & $\begin{array}{l}\text { Best } \\
\text { model }\end{array}$ & $\begin{array}{l}\text { Initial } \\
\text { model }\end{array}$ & $\begin{array}{l}\text { Best } \\
\text { model }\end{array}$ & $\begin{array}{l}\text { Initial } \\
\text { model }\end{array}$ & $\begin{array}{l}\text { Best } \\
\text { model }\end{array}$ & $\begin{array}{l}\text { Initial } \\
\text { model }\end{array}$ & $\begin{array}{l}\text { Best } \\
\text { model }\end{array}$ & $\begin{array}{l}\text { Initial } \\
\text { model }\end{array}$ & $\begin{array}{l}\text { Best } \\
\text { model }\end{array}$ \\
\hline $\begin{array}{l}\text { Smoker B } \\
\text { p } \\
\text { Ex-smoker B } \\
\text { p } \\
\text { Latency B } \\
\text { p } \\
\text { Chest } x \text { ray film B } \\
\text { abnormalities p } \\
\text { Dyspnoea B }\end{array}$ & $\begin{array}{c}-2 \cdot 089 \\
0.74 \\
5.04 \\
0.42 \\
-1.078 \\
0.02 \\
-5 \cdot 452 \\
0.26 \\
-0.90 \\
0.88\end{array}$ & $\begin{array}{r} \\
-0.96 \\
0.03\end{array}$ & $\begin{array}{c}-6.87 \\
0.39 \\
2.97 \\
0.71 \\
-1.33 \\
0.025 \\
-3.03 \\
0.625 \\
0.66 \\
0.93\end{array}$ & $\begin{array}{c}0.11 \\
-1 \cdot 045 \\
\end{array}$ & $\begin{array}{c}-5 \cdot 398 \\
0 \cdot 32 \\
-2 \cdot 145 \\
0.69 \\
-0 \cdot 21 \\
0 \cdot 59 \\
4 \cdot 76 \\
0 \cdot 26 \\
-0 \cdot 27 \\
0.96\end{array}$ & $\begin{array}{l}5 \cdot 28 \\
0 \cdot 18\end{array}$ & $\begin{array}{r}-18.95 \\
0.17 \\
-2.88 \\
0.83 \\
-1.80 \\
0.071 \\
3.32 \\
0.75 \\
1.42 \\
0.92\end{array}$ & $\begin{array}{c}-19 \cdot 41 \\
0 \cdot 133 \\
-3 \cdot 66 \\
0.78 \\
-1 \cdot 78 \\
0.066 \\
\end{array}$ & $\begin{array}{c}-4 \cdot 856 \\
0.485 \\
-2.932 \\
0.677 \\
-0 \cdot 175 \\
0.73 \\
-16 \cdot 35 \\
0.004 \\
-10 \cdot 91 \\
0.115\end{array}$ & $\begin{array}{r}-15.79 \\
0.003 \\
-11.76 \\
0.067\end{array}$ & $\begin{array}{r}0.163 \\
0.374 \\
0.126 \\
0.5 \\
0.013 \\
0.327 \\
-0.072 \\
0.614 \\
-0.013 \\
0.944\end{array}$ & & $\begin{array}{c}-75 \cdot 8 \\
0 \cdot 081 \\
-71 \cdot 4 \\
0 \cdot 105 \\
2 \cdot 844 \\
0 \cdot 356 \\
34 \cdot 4 \\
0 \cdot 3 \\
6 \cdot 31 \\
0 \cdot 88\end{array}$ & $\begin{array}{r}88.97 \\
0.03 \\
-76.77 \\
0.074\end{array}$ \\
\hline
\end{tabular}


Table 7 Regression coefficients ( $B$ ) between the independent variables-smoking state, latency, chest $x$ ray film abnormalities and dyspnoea, and the dependent variables_right ventricular ejection fractions at rest $(R V E F-R)$, during exercise ( $R V E F-$ $E)$, and change between rest and exercise ( $R V E F-C H N G)$

\begin{tabular}{|c|c|c|c|c|c|c|}
\hline \multirow[b]{2}{*}{ Category } & \multicolumn{2}{|l|}{$R V E F-R$} & \multicolumn{2}{|l|}{$R V E F-E$} & \multicolumn{2}{|c|}{$R V E F-C H N G$} \\
\hline & Initial model & Best model & Initial model & Best model & Initial model & Best model \\
\hline $\begin{array}{l}\text { Smoker B } \\
\text { p } \\
\text { Ex-smoker B } \\
\text { p } \\
\text { Latency B } \\
\text { p } \\
\text { Chest } x \text { ray film B } \\
\text { abnormalities p } \\
\text { Dyspnoea B } \\
\text { p }\end{array}$ & $\begin{array}{l}0.145 \\
0.96 \\
0.403 \\
0.90 \\
0.045 \\
0.82 \\
-2.25 \\
0.31 \\
2.14 \\
0.51\end{array}$ & & $\begin{array}{c}1.401 \\
0.71 \\
1.277 \\
0.74 \\
-0.213 \\
0.39 \\
-6.42 \\
0.027 \\
-1.456 \\
0.72\end{array}$ & $\begin{array}{c}-6.92 \\
0.009\end{array}$ & $\begin{array}{c}1 \cdot 546 \\
0.64 \\
0 \cdot 874 \\
0 \cdot 80 \\
-0 \cdot 259 \\
0 \cdot 24 \\
-4 \cdot 12 \\
0.091 \\
-3 \cdot 596 \\
0.32\end{array}$ & $\begin{array}{c}-4.52 \\
0.049\end{array}$ \\
\hline
\end{tabular}

Also, a significantly lower mean value of $\mathrm{D}_{\mathrm{L}} \mathrm{CO}$ was found for the group with abnormal chest radiographs as compared with the workers with normal $x$ ray films $(t=3.09$; df 39.0; $p=0.0037)$.

\section{RADIONUCLIDE VENTRICULOGRAPHY}

The overall left and right ventricular ejection fractions were normal, but those with abnormal chest radiographs had significantly lower right ventricular ejection fractions on exercise (RVEF-E) than those with normal chest $x$ ray films $(t=2.82 ; p=0.009)$. No difference was found for left ventricular function between the two groups. Furthermore, chest radiographic abnormalities (as ILO profusion score or as categorised variable) were inversely correlated with right ventricular ejection fraction during exercise $(\mathrm{r}=-0.46 ; \mathrm{p}=0.01)$ and $(\mathrm{r}=-0.47 ; \mathrm{p}=0.008$ respectively). Moreover, the correlation coefficient between ILO profusion score and right ventricular ejection fraction at rest was $-0.32, p=0.08$. Right ventricular ejection fraction at rest and during exercise was associated with diffusing capacity and the correlations reached borderline statistical significance $(r=0.33 ; p=0.07$ and $r=0.33 ; p=0.07)$. Other detailed results from the cardiological investigation have been presented elsewhere. ${ }^{19}$

\section{REGRESSION ANALYSES}

Tables 6 and 7 summarise the results of the multivariate regression analyses. Time since onset of employment (latency) was significantly associated with parameters of both restrictive and obstructive pulmonary function. Furthermore, there was an association between chest radiographic abnormalities (scores on the ILO scale) and diffusing capacity, diffusing capacity being a more sensitive indicator of interstitial lung disease than the spirometric parameters. The association between dyspnoea and diffusing capacity reached borderline statistical significance. Of additional interest is the noted association between findings on chest $x$ ray films, right ventricular ejection fraction on exercise, and the change in ejection fraction occurring on exercise.

\section{Discussion}

The manufacture of hard metal alloys began in Germany shortly after the first world war. The earliest report of health hazards in the German hard metal industry was published in 1940 . A survey of 27 workers showed eight with radiographic abnormalities consistent with "early dust disease". ${ }^{20}$ A relation was found between bronchitis, radiographic findings and particle size, duration and intensity of exposure. Abnormal chest radiographs appeared after short duration of employment-that is, between one and two years.

A detailed description of industrial hygiene and medical investigations was provided in 1954 by investigators of the Swedish hard metal industry, which developed rapidly during the 1930s. ${ }^{21}$ Subsequent to these early observations, it has become evident that the pulmonary effects of excessive exposure to hard metals can manifest themselves as various clinical entities-namely, asthma, pneumonitis, and interstitial fibrosis. ${ }^{22-24}$ The long latency period between onset of exposure and clinical manifestation of disease, so typical for many pneumoconioses such as silicosis and asbestosis, usually does not apply to hard metal disease. ${ }^{2021}$ It has also been noted that some of the disease processes can regress, as reflected by the normalisation of chest radiographs after removal of the subjects from exposure and treatment with corticosteroids. ${ }^{25} 26$ Progression of the disease, however, was described in some of the earlier reports even after discontinuation of exposure. ${ }^{21}$

It is generally thought that cobalt is the main aetiological factor in hard metal disease. This has been demonstrated in experimental studies which have received clinical confirmation by reports of hard metal disease in workers exposed to cobalt dust alone in the absence of the other common constituents of 
hard metal alloys. ${ }^{5}$ The high solubility of cobalt in plasma prevents it from accumulating in tissues. Thus in many instances cobalt cannot be identified in biopsy specimens of lung tissue from subjects who were not exposed at the time of the acquisition of the tissue sample. ${ }^{1326}$

Our present investigation was prompted by the finding of two cases of hard metal disease in workers who had been diagnosed with the disease after four and five years of employment during the 1960 s in a hard metal manufacturing plant. ${ }^{13}$

The results of this investigation of a group of 41 workers with previous employment in hard metal processing plants indicate that adverse pulmonary effects of excessive exposure to hard metals can occur with appreciable prevalence even in the modern industry. Almost one third of the examined workers had radiographic evidence of interstitial lung disease; in two instances the diagnosis had been confirmed by histopathological analysis and identification of hard metal components in the lung tissue. It is of interest to note that a third subject from our study population, in whom we did not find any certain radiographic or pulmonary function abnormalities, but who presented with respiratory symptoms, had a transbronchial biopsy taken which showed features typical of hard metal disease by electron microscopy and microchemical analysis of lung tissue (Abraham J. Personal communication). The presence of respiratory symptoms such as productive cough and shortness of breath in the absence of radiographic abnormalities has been reported in workers exposed to hard metals and it is likely that this combination represents the bronchitic and inflammatory stage of the disease process. ${ }^{27}$ The presence of other interstitial lung diseases in the absence of radiographic abnormalities has also been reported. ${ }^{28}$

Of special note is our finding that almost half of the examined workers with abnormal chest radiographs had been employed in hard metal manufacturing for less than 10 years. This observation explains the lack of association between $x$ ray film abnormalities, duration of employment and duration from onset of employment. The impairment in pulmonary function, however, was more closely related to duration of employment and duration from onset of work.

Although the lack of information on industrial hygiene prevents any conclusions with regard to dose-response relations, it is a widely held opinion that the handling and pressing of the metal powders (pre-sintered) is the more hazardous activity compared with the grinding of the finished hard metal object (sintered). Those with the most severe radiographic abnormalities in our study population had, at one time or another, directly handled the metal powders. The proximity of the various operations to each other in the factory makes it difficult, however, to associate a certain manufacturing process with the development of clinical abnormalities in this group of workers.

The high prevalence of respiratory symptoms in the studied group is remarkable. The examined subjects were volunteers, however, and the study group should not be considered as a population selected from the total workforce by specific criteria.

Despite this, a high prevalence of abnormalities in pulmonary function was found; one third of those examined had evidence of a restrictive pattern of impairment, and $28 \%$ had low $\mathrm{D}_{\mathrm{L}} \mathrm{CO}$. Abnormalities in $\mathrm{FVC}$ and $\mathrm{D}_{\mathrm{L}} \mathrm{CO}$ were more common among those with abnormal chest radiographs. Furthermore, the workers with abnormal chest radiographs had a significantly lower mean value of diffusing capacity compared with those with normal $x$ ray films $(p<0.01)$. The prevalence of obstructive impairment among this group of workers was low-namely, $15 \%$. Logisitic regression analysis showed an association between chest radiographic abnormalities and diffusing capacity. Moreover, the findings on $x$ ray film were associated with right ventricular ejection fraction and with the change in ejection fraction recorded on exercise. Thus an increase in ILO profusion score was accompanied by a decrease in right ventricular ejection fraction suggesting a pathophysiological correlate to the observed radiological findings.

Various abnormalities of pulmonary function have been reported among hard metal workers by several investigators. The irritative or allergic effects associated with exposure to cobalt are usually manifested by obstructive patterns of impairment. ${ }^{2930}$ Detailed studies of workers with well defined exposures (mean air cobalt concentration of $60 \mu \mathrm{g} / \mathrm{m}^{3}$ ) have shown primarily obstructive abnormalities in the absence of radiographic findings. Such impairment was noted to occur during a single eight hour day with further decrease in function over the next few days. Comparison between exposed and control groups also showed significant differences after a period of four weeks away from exposure. Therefore a chronic effect on pulmonary function was suggested. ${ }^{31}$ In a five year follow up study, the occupationally exposed smokers were found to have a more significant decrement in lung function than non-smokers. ${ }^{32}$

Acute respiratory symptoms and pulmonary dysfunction consistent with occupational asthma have been reported among hard metal workers. Positive bronchial provocation tests to cobalt and the presence of specific antibodies have also been described..$^{334}$ Acute and short term responses were not investigated in the present study as our study subjects had a history of past exposure to hard metals.

The results of our study suggest, however, that most of the abnormalities observed by us are mani- 
festations of hard metal disease-that is, interstitial pulmonary fibrosis whereas signs of the asthmatic and bronchitic manifestations of hard metal lung disease were less prevalent. The radiographic findings and results of pulmonary function tests are consistent. The high prevalence of radiographic abnormalities in our investigation differs from those reported in other recent studies of larger populations. ${ }^{35}{ }^{36}$ It should be noted that our study population consisted of workers who had been employed in hard metal manufacturing previously and that they were not selected from a currently employed work population. They were examined because of concern over the presence of health effects potentially related to their previous employment. This is by contrast with the study populations of other recent investigations, which were concerned with the prevalence of health effects among workers actively employed in hard metal manufacturing, without including persons who might have retired or left their employment because of intolerance to the work environment; this situation may be particularly relevant to those who developed occupational asthma. It should be noted, however, that in one of the recent cross sectional studies, in which findings among 425 exposed hard metal workers were reported ${ }^{36}$ the prevalences of radiographic abnormalities in two subgroups of workers employed in the powder and press workshops were $24 \%$ and $19.5 \%$ respectively.

In two of our cases lung biopsies had been taken because of previously noted abnormal chest radiographs and respiratory symptoms; hard metal disease was diagnosed by the characteristic features of giant cell interstitial pneumonia and fibrosis. The association between the histopathological observations and the exposure source was strengthened by the findings obtained by energy dispersive $x$ ray microanlysis of lung tissue. ${ }^{1377}$

Inferences should not be drawn from this study as to the prevalence of hard metal disease in the United States in general. The results suggest, however, that further epidemiological studies are warranted and that industrial hygiene control measures are needed to minimise the future occurrence of this occupational lung disease, the history of which now enters the sixth decade since its first published description.

Requests for reprints to: Alf Fischbein MD, Visiting Professor, The Institute for Occupational Health, Sackler Faculty of Medicine, Tel Aviv University, Ramat Aviv, Tel Aviv 69978, Israel.

1 Bech AO, Kipling MD, Heather JC. Hard metal disease. $\mathrm{Br} \mathrm{J}$ Ind Med 1962;19:239-52.

2 Scherrer M, Maillard JM. Hartmetall-Pneumopathien. Schweiz Med Wochenschr 1982;112:198-207.

3 Rüttner JR, Spycher MA, Stolkin L. Inorganic particulates in lungs of hard metal grinders. Br J Ind Med 1987;44:657-60.
4 Schepers GWH. The biological action of particulate cobalt metal. Archives of Industrial Health 1955;12:127-33.

5 Demedts N, Gheysens B, Nagels J, Verbeken E, Lauweryns J, Van den Eeckhout $A$, et al. Cobalt lung in diamond polishers. Am Rev Respir Dis 1984;130:130-5.

6 van der Eekhout AV, Verbeken E, Demedts M. Pulmonary pathology due to cobalt and hard metals. Rev Mal Respir 1989;6:201-7.

7 Abraham JL, Hertzberg MA. Inorganic particulates associated with desquamative interstitial pneumonia. Chest 1981; 80(suppl):67s-70s.

8 Austenfeld JL, Colby TV. Recognizing lung disease induced by hard metal exposure. Journal of Respiratory Diseases 1989; 10:65-75.

9 Davison AG, Haslam PL, Corrin B, Coutts II, Dewar A, Riding WD, et al. Interstitial lung disease and asthma in hard-metal workers: bronchoalveolar lavage, ultrastructural, and analytical findings and results of bronchial provocation tests. Thorax 1983;38:119-28.

10 Barborik M, Dusek J. Cardiomyopathy accompanying industrial cobalt exposure. Br Heart J 1972;34:113-16.

11 Kesteloot H, Roelandt J, Willems J, Claes JH, Joossens JV. An enquiry into the role of cobalt in the heart disease of chronic beer drinkers. Circulation 1968;27:854-63.

12 Fischer T, Rystedt J. Cobalt allergy in hard metal workers. Contact Dermatitis 1983;9:115-21.

13 Fischbein A, Abraham JL, Horowitz SF, Hailoo WL, Cohen BA, Rizzo JN, et al. Hard metal disease: A multidisciplinary evaluation of two cases. New York State Journal of Medicine 1986;86:600-3.

14 Interational Labour Office. Guidelines for the use of ILO international classification of radiographs of pneumoconioses. Rev ed. Geneva: ILO, 1980. (Occupational Health and Safety series no 22.)

15 Ferris BG (Principal Investigator). Epidemiology standardization project. Am Rev Respir Dis 1978;118: Part 2.

16 Morris JF, Temple WP, Koski A. Normal values for the ratio of one-second forced expiratory volume to forced vital capacity. Am Rev Respir Dis 1973;108:1000-3.

17 Miller A, Thornton JC, Smith H Jr, Morris JF. Spirometric "abnormality" in a normal male reference population: Further analysis of the 1971 Oregon Study. Am J Ind Med 1980;1: 55-68.

18 Miller A, Thornton JC, Warshaw R, Anderson H, Teirstein AS, Selikoff IJ. Single breath diffusing capacity in a representative sample of the population of Michigan, a large industrial state: Predicted values, lower limits of normal, and frequencies of abnormality by smoking history. Am Rev Respir Dis 1983; 127:270-7.

19 Horowitz SF, Fischbein A, Matza D, Rizzo JN, Stern A, Machac J, Solomon SJ. Evaluation of right and left ventricular function in hard metal workers. Br J Ind Med 1988;45:742-6.

20 Jobs H, Ballhausen C. Metallkeramik als Staubquelle vom ärztlichen und technischen Standpunkt. Vertrauensarzt und Krankenkasse 1940;8:142-8.

21 Lundgren KD, Öhman H. Pneumoconiose in der Hartmetallindustrie: Technische und medizinische Untersuchungen. Virchows Arch 1954;325:259-84.

22 Bruckner HC. Extrinsic asthma in a tungsten carbide worker. J Occup Med 1967;9:518-9.

23 Coates EO Jr, Watson JH. Diffuse interstitial lung disease in tungsten carbide workers. Ann Intern Med 1971;75:709-16.

24 Hartmann A, Wutrich B, Bolognini G. Berufsbedingte Lungenkreitheiten bei der Hartmetall Production und Bearbeitung. Ein Allergisches Geschehen? Schweiz Med Wochenschr 1982;112:1137-41.

25 Sjögren I, Hillerdal G, Andersson A, Zetterstrom O. Hard metal lung disesae: Importance of cobalt in coolants. Thorax 1980;35:653-9.

26 Anttilla S, Sutinen S, Paananen M, Kreus KE, Sivonen SY, Grekula A, Alapieti T. Hard metal lung disease: A clinical, histological, ultrastructural and $x$-ray microanalytical study. Eur J Respir Dis 1986;69:83-94.

27 Parkes WR. Occupational lung disorders, 2nd ed. London: Butterworths 1982:464-7.

28 Epler, GR, Mcloud TC, Gaensler EA, Mikus JP, Carrington CB. Normal chest roentgenograms in chronic diffuse infiltrative lung disease. $N$ Engl J Med 1978;298:934-9.

29 Alexandersson $R$. Undersökningar över effekter av exposition för kobolt. II Reaktioner $\mathrm{i}$ andningsorganen vid olika grad av exposition i hảrdmetallindustrin. Arbete och Hälsa 1979;2: 1-34. (In Swedish with English summary.)

30 Kusaka Y, Ichikawa Y, Shirakawa T, Goto S. Effect of hard metal 
dust on ventilatory function. $B r J$ Ind Med 1986;43:485-9.

31 Alexandersson $R$. Undersökningar över effekter av exposition för kobolt. VI. Exposition, upptag och lungpåverkan av kobolt i hårdmetallindustrin. Arbete och Hälsa 1979;10:1-24. (In Swedish with English summary.)

32 Alexandersson R. Effekter av exponering för kobolt $i$ hårdmetallindustrin. En 5-àrsuppföljning. Arbete och Hälsa 1986;27:3-19. (In Swedish with English summary.)

33 Shirakawa T, Kusaka Y, Fujimura N, Goto S, Kato M, Heki S, Morimoti K. Occupational asthma from cobalt sensitivity in workers exposed to hard metal dust. Chest 1989;95:29-37.

34 Shirakawa T, Kusaka Y, Fujimura N, Goto S, Morimoto K. The existence of specific antibodies to cobalt in hard metal asthma. Clin Allergy 1988;18:451-60.
35 Sprince NL, Oliver LC, Eisen EA, Greene RE, Chamberlin RI. Cobalt exposure and lung disease in tungsten carbide production. Am Rev Respir Dis 1988;138:1220-6.

36 Meyer-Bisch C, Pham QT, Mur JM, Massin N, Moulin JJ, Tecelescu D, et al. Respiratory hazards in hard metal workers A cross sectional study. Br J Ind Med 1989;46:302-9.

37 Abraham JL, Burnett BR, Hunt A. Development and use of a pneumoconiosis database of human pulmonary inorganic particulate burden in over 400 lungs. Scanning Microscopy 1991;5:95-108.

Accepted 13 May 1991

\section{Vancouver style}

All manuscripts submitted to the $\mathrm{Br} J$ Ind Med should conform to the uniform requirements for manuscripts submitted to biomedical journals (known as the Vancouver style).

The $\mathrm{Br} J$ Ind Med, together with many other international biomedical journals, has agreed to accept articles prepared in accordance with the Vancouver style. The style (described in full in $\mathrm{Br}$ Med J, 24 February 1979, p 532) is intended to standardise requirements for authors.

References should be numbered consecutively in the order in which they are first mentioned in the text by Arabic numerals above the line on each occasion the reference is cited (Manson ${ }^{1}$ confirmed other reports $\left.{ }^{2-5} \ldots\right)$. In future references to papers submitted to the $B r J$ Ind Med should include: the names of all authors if there are six or less or, if there are more, the first three followed by et al; the title of journal articles or book chapters; the titles of journals abbreviated according to the style of Index Medicus; and the first and final page numbers of the article or chapter.

Examples of common forms of references are:

1 International Steering Committee of Medical Editors. Uniform requirements for manuscripts submitted to biomedical journals. $\mathrm{Br}$ Med J 1979;1:532-5.

2 Soter NA, Wasserman SI, Austen KF. Cold urticaria: release into the circulation of histamine and eosino-phil chemotactic factor of anaphylaxis during cold challenge. N Engl J Med 1976;294:687-90.

3 Weinstein L, Swartz MN. Pathogenic properties of invading micro-organisms. In: Sodeman WA Jr, Sodeman WA eds. Pathologic physiology: mechanisms of disease. Philadelphia: W B Saunders, 1974:457-72. 